\title{
Genetic Modification of Intestinal Lactobacilli and Bifidobacteria
}

\author{
Martin J. Kullen and Todd R. Klaenhammer* \\ Dept. of Food Science, North Carolina State University, \\ Raleigh, NC 27695-7624, USA
}

\begin{abstract}
Lactobacilli and bifidobacteria are important members of the gastrointestinal microflora of man and animals. There is a substantial and growing body of evidence that these microbes provide benefits to the host in which they reside. Understanding the roles of these two groups of bacteria in the intestine continues to be a significant challenge. To this end, genetic characterisation and manipulation of intestinal lactobacilli and bifidobacteria is essential to define their contributions to the intestinal microflora, and to potentially exploit any beneficial or unique properties. This review will describe the tools and strategies currently available for the genetic manipulation of lactobacilli and bifidobacteria. Additionally, the ramifications and opportunities that may arise as a result of the genetic manipulation of probiotic lactobacilli and bifidobacteria will be addressed.
\end{abstract}

\section{Introduction}

The gastrointestinal tract of vertebrate animals is the most densely colonized region of the human body $(112,127)$. There are approximately $10^{12}$ bacteria per gram of contents in the large intestine, which is estimated to contain several hundred bacterial species (99). The accumulated evidence indicates that this collection of microbes has a powerful influence on the host in which it resides. Comparisons between germfree and conventional animals have shown that many biochemical, physiological and immunological functions are influenced by the presence of the diverse and metabolically active bacterial community residing in the gastrointestinal tract $(80,111,112)$.

The use of live microbes as dietary adjuncts or probiotics has received considerable commercial and scientific attention (127). Fuller (34) defined a probiotic as a "live microbial feed supplement which beneficially affects the host animal by improving its intestinal microbial balance." This definition was broadened by Havenaar and Huis in't Veld (41) to a "mono- or mixed-culture of live microorganisms" which benefits man or animals by improving the properties of the indigenous microflora. A number of excellent overviews are available on probiotics $(8,27,36,37,60,81,94,95)$. The potential health benefits attributed to probiotics include the following:

- maintenance of the normal microflora

- pathogen interference, exclusion, and antagonism

- immunostimulation and immunomodulation

- anticarcinogenic and antimutagenic activities

- alleviation of symptoms of lactose intolerance

- reduction in serum cholesterol
Many of the effects attributed to the ingestion of probiotics, however, remain convoluted and scientifically unsubstantiated (81), and it is rare that specific health claims can be made (96). This situation could be resolved by providing exact descriptions of the probiotic microorganisms involved and developing an understanding of the control mechanisms for those functional properties that are vital to the survival and activity of these organisms in the human gastrointestinal tract. However, the perceived desirable qualities of probiotics are many (Table 1), and it is highly unlikely that any one strain will harbor all the qualities or provide the multitude of proposed benefits. There is a myriad of possible probiotic strains, coupled with a highly diverse set of phenotypes and potential benefits. Therefore, screening genetic traits offers considerable promise in attacking the almost insurmountable task of surveying for functional probiotic properties, or building combinations of probiotic strains that can elicit multiple effects. Moreover, genetic modification of probiotic bacteria offers the added developmental potential to annex new beneficial activities (e.g. vaccine presentation) or improve the effectiveness of existing properties (e.g. bacteriocin levels).

Lactobacilli and bifidobacteria constitute two extremely important groups of probiotic bacteria. As members of the normal microflora of the gastrointestinal tract of humans, they offer considerable potential as probiotics because of their history of safe use and the general body of evidence that supports their positive roles. Genetic analysis and manipulation of these bacteria will be paramount to understanding their probiotic roles and maximising their performance in vitro and in vivo. The field is now poised to exploit genetic approaches in the investigation of these bacteria and their probiotic capabilities. However, recent surges in the development of genetic tools for lactic acid bacteria have lagged significantly for bifidobacteria and intestinal lactobacilli. Genetic work on bifidobacteria is in its infancy. For the lactobacilli, there have been a number of significant developments (reviewed in 53, 86). However, these efforts have been dispersed over a collection of newly recognized, and collectively significant probiotic lactobacilli (e.g. Lactobacillus acidophilus, Lactobacillus gasseri, Lactobacillus johnsonii, Lactobacillus reuteri, Lactobacillus plantarum, Lactobacillus casei, Lactobacillus paracasei) resulting in only incremental steps in our understanding of the genetic programming and potential of the Lactobacillus species, overall. The following is intended to overview the tools available for genetic manipulation of lactobacilli and bifidobacteria and discuss opportunities for genetic analysis and modification of these two key groups of probiotic bacteria.

\section{Lactobacilli}

Members of the genus Lactobacillus constitute an extremely diverse and important group of organisms, of 


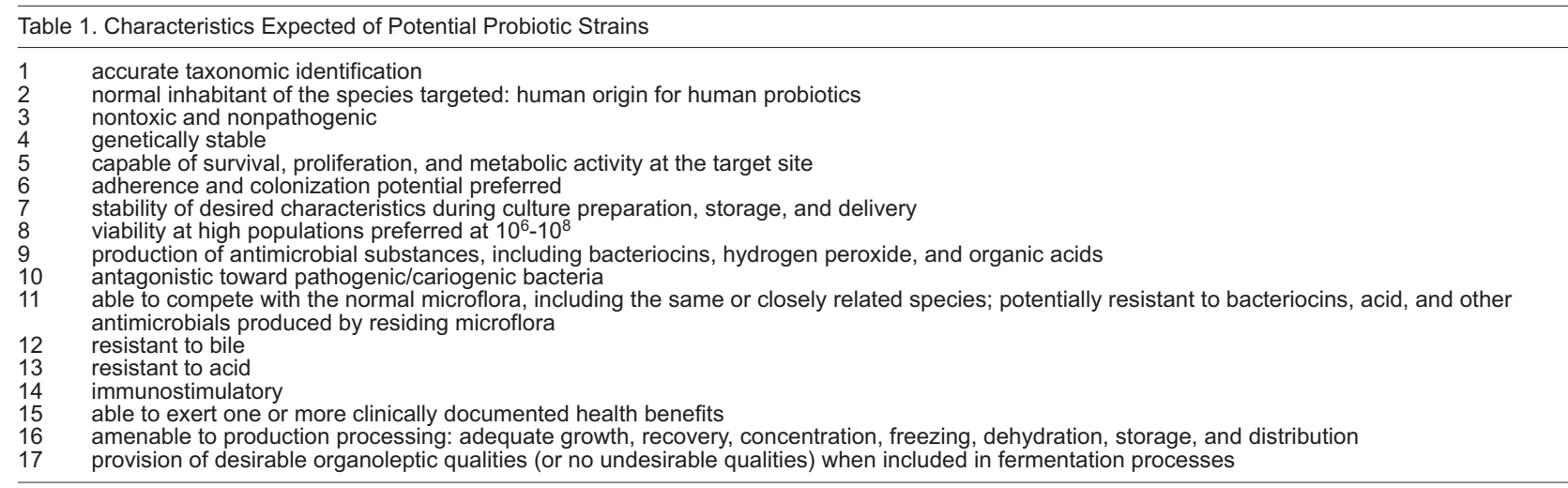

which some are members of the colonic microflora. $L$. acidophilus has been considered the most important of the gastrointestinal lactobacilli, but in 1980 (58), the group of organisms previously known as "L. acidophilus "was shown to be highly heterogeneous. The species was, subsequently, separated into the DNA homology groups, $A$ and $B$, which now form six separate species: $L$. acidophilus, Lactobacillus amylovorus, Lactobacillus crispatus, Lactobacillus gallinarum, $L$. gasseri and $L$. johnsonii $(33,47,58)$. While the name of acidophilus was retained by the neotype strain, ATCC 4356 , this species is not the dominant lactobacillus found in the intestine of man and other vertebrate animals (75). In addition to the species comprising the L. acidophilus group, Lactobacillus salivarius, L. casei, L. plantarum, L. reuteri and Lactobacillus brevis are found in the gastrointestinal tract of humans and other animals, including avians.

\section{Lactobacillus Plasmids and Vectors}

The genetic analysis and modification of lactobacilli was ushered in by the discovery of broad host-range plasmids and the development of electroporation procedures for DNA transformation. Current cloning vectors for lactobacilli fall into three classes: promiscuous plasmids based on RCR (rolling circle replication) replicons, plasmids with two replication origins for Escherichia coli and gram-positive bacteria, and native Lactobacillus vectors with selectable markers and alternative replication origins for gramnegative bacteria. The prototype vector of the RCR replicon class is pGK12, which is based upon pWVO1 and contains erythromycin $\left(\mathrm{Em}^{r}\right)$ and chloramphenicol $\left(\mathrm{Cm}^{r}\right)$ resistance markers which were selectable in lactococci, E. coli, Bacillus subtilis (55), and most Lactobacillus species including L. acidophilus, L. gasseri, L. johnsonii, L. plantarum, L. casei, Lactobacillus fermentum, and L. reuteri (65). The second category of vectors contains two origins, one functional in E. coli and the second in gram-positive bacteria. The most widely used vector of this class is pSA3 (24), which has proven to be particularly useful both as cloning and integration vector in $L$. johnsonii, L. gasseri, and Lactobacillus helveticus $(11,87,121)$. A pair of highand low-copy number vectors (pTRKL/H), functional in lactobacilli, were constructed using the broad gram-positive host range pAMB1-based replicons pIL252 (low copy) and
pIL253 (high copy) (109) and an E. coli P15A origin (82). $\mathrm{pTRKL} / \mathrm{H}$ series vectors replicate via a theta mechanism which is broadly functional across lactobacilli and provides more structural stability to recombinant plasmids since a ssDNA intermediate is not involved. These vectors work well in L. johnsonii and L. gasseri, but not in L. acidophilus. The third vector design incorporates selectable markers and alternative replication origins for gram-negative bacteria to small cryptic Lactobacillus plasmids, a number of which have been completely sequenced $(13,15,65$, $73,86,98)$. Plasmid vectors based on RCR Lactobacillus replicons marked with $\mathrm{Em}^{\mathrm{r}}$ and/or $\mathrm{Cm}^{\mathrm{r}}$, lacZ or $x y l$ (xylose catabolism) have been compiled by Pouwels and Leer (86) and continue to appear $(50,54,120)$. In some cases, the host range of Lactobacillus-based vectors includes lactobacilli and other gram-positive bacteria, but not $E$. coli $(85,86)$. However, several replicons of plasmids isolated from Lactobacillus have now been found that have a broader host range, allowing replication in E. coli, Bacillus, and various lactic acid-producing bacteria (LAB) and include: pPSC20/pPSC22 (20), pLC2 (54), pGT633 (115), pA1 (120) and pLA106 (98). Vectors of this type may be useful for genetic modification and analysis of intestinal lactobacilli, in which other RCR or theta replicons are unstable. In contrast, plasmids with limited host range replicons have been identified in $L$. reuteri (1) and $L$. crispatus (86). As noted by Pouwels and Leer (86), these vectors may be particularly useful in the development of food/vaccine-grade vectors as their small host range makes them much less likely to promote horizontal gene transfer to other bacterial species.

\section{Electrotransformation}

Electroporation has been used widely for gene transfer and cloning in many lactobacilli $(6,10,17,65,85)$. Transformation of intestinal lactobacilli at reasonable frequencies has been reported widely for $L$. gasseri, $L$. johnsonii, and $L$. reuteri $(1,31,50,64,65,66,77,115)$, and these species appear highly amenable for DNA manipulation and gene transfer. However, electroporation protocols that are effective for many lactobacilli have not yielded transformants of type A1, $L$. acidophilus strains. Early reports of electroporation of " $L$. acidophilus" from our laboratory $(64,65)$ actually involved strains of $L$. gasseri and $L$. johnsonii strains which were reclassified on the basis 
of the new taxonomy for the "L. acidophilus" group (33, 57). Kanatani et al. (50) constructed an Em $\mathrm{Em}^{\mathrm{r}}$-vector using a small plasmid from $L$. acidophilus TK8912 and noted transformation frequencies near $10^{7} / \mu \mathrm{g}$ DNA. The taxonomy of this strain has not been reported with reference to the new classifications. Recently, we have successfully transformed two type-A1 L. acidophilus strains with minor modifications to the method developed by Bhowmick and Steele (10) for L. helveticus (122). L. acidophilus ATCC 4356 (A1-neotype) and ATCC 700396 (NCFM/N2) were transformed with pGK12 and pGhost (67) at frequencies ranging from $10-10^{2}$ transformants/ $\mu \mathrm{g}$ DNA. While these frequencies are low when compared to other species transformable at $10^{5}-10^{7} / \mu \mathrm{g}$, they provide opportunities for genetic modification and experimentation with these two important $L$. acidophilus strains, one the neotype and the second, a commercial strain distributed widely in acidophilus milk and a variety of dietary-health products.

\section{Conjugation}

While broad host range vectors like pAMB1 and pVA797 are transmissible from heterologous donors (Lactococcus and Enterococcus) to lactobacilli, reports of native conjugation systems in lactobacilli are few. L. gasseri transconjugants did not act as donors for second round transfers (64) whereas $L$. reuteri transconjugants could transfer $\mathrm{pAMB} 1$ to $L$. reuteriand $E$. faecalis (114). Conjugal transfer of plasmid-associated lactose fermenting ability in L. casei was reported by Chassy and Rokaw (19). Since this initial report, however, the only evidence which has appeared for a native conjugal system in Lactobacillus species is in L. johnsonii (76). Bacteriocin (lactacin F) production and immunity in L. johnsonii VPI11088 (NCK88) is chromosomally encoded on a conjugative episomal element $(30,77)$. This conjugation system was employed to mobilize pSA3 in conjugation experiments from $L$. johnsonii (pSA3) donors leading to the recovery of a pSA3 resolution product carrying IS1223(121). This IS-element is functional in L. gasseri, L. johnsonii, and L. acidophilus. While it is clear that conjugation is a mechanism for gene transfer in lactobacilli, the extent and usefulness of conjugative systems have not been examined to a significant degree. Because many of the type A1 strains of the $L$. acidophilus group are recalcitrant to electroporation, conjugation may be a more useful and potentially broader range tool for gene transfer in lactobacilli.

\section{Integration and Insertion Systems}

Integration of genes/vectors into the bacterial chromosome is a critical genetic tool for insertional mutagenesis, creation of physical/genetic maps, and directed manipulations such as gene stabilization, fusion, amplification, deletion, and replacement. In the lactobacilli, a number of new technologies are emerging that utilize IS-elements, attP/ integrase systems, or homologous recombination strategies via suicide or temperature-sensitive replicons.

Several different IS elements have been found in lactobacilli $(108,110,121,126)$. One of these IS elements, IS 1223, has been used for construction of suicide integration vectors using pSA3 (121) and pGhost replicons (Aoyama, Walker and Klaenhammer, unpublished). Integration experiments have demonstrated that IS1223 directs random insertions in L. acidophilus and $L$. gasseri chromosomes where there is no detectable homology for the IS element. In contrast, insertions in L. johnsonii, where resident copies of IS 1223 are found, show a site preference. While their use as stable integration vectors would be limited due to their propensity for additional transposition events, the discovery of functional IS elements in lactobacilli should aid in the development of functional mutagenesis and insertional vectors for a variety of intestinal lactobacilli.

Establishment of the prophage state by temperate bacteriophages is a highly efficient and site-specific integration system. Insertion at a specific chromosomal location (attB) is mediated by a small region of homology on the phage (attP) and a phage-encoded integrase (int). The attP and int $G$ of the $L$. gasseri temperate phage $\phi a d h$ have been cloned, sequenced, and used for construction of site-specific suicide integration vectors $(31,87)$. While the vectors are functional across strains of $L$. gasseri, the attB sequence is not conserved in other intestinal lactobacilli (DeAntoni, Fremaux, Raya, and Klaenhammer, unpublished). The attP and int $G$ of the $L$. delbrueckii subsp. bulgaricus temperate phage mv4 have also been used in the construction of a site-specific integration vector (7). A particularly attractive aspect of this system is that the integration site for the vector is at the $3^{\prime}$ end of a tRNA ${ }^{\text {Ser }}$ gene and occurs without inactivation of this gene in lactobacilli. There are several advantages that phagebased integration systems offer for the genetic manipulation of lactobacilli for food or medical applications: insertions are stable and at single copy; large fragments encoding complex operons could be integrated; and, insertions occur at a specific, non-essential site that should not disrupt culture viability or activity.

Homologous recombination has been used extensively in the construction of integration vectors for accomplishing gene disruption, amplification, replacement, and insertions in a variety of bacteria. An important element for integration experiments is a reasonable frequency of electroporation since generation of integrants relies on both successful transformation and recombination events. As noted earlier, transformation via electroporation can be applied throughout the lactobacilli, but many species are transformable at frequencies that are only marginal for many integration experiments. To circumvent problems with low efficiencies, autoreplicating or temperature-sensitive plasmids, that replicate conditionally or are unstable in the absence of selection, should be employed. While the pGhost series of vectors contain temperature sensitive origins (67), these plasmids are problematic in lactobacilli because outgrowth of transformants at the permissive temperature $\left(28^{\circ} \mathrm{C}\right)$ is very inefficient. Both pSA3 $(3,10$, 88 , Walker and Klaenhammer, unpublished) and pGK12type plasmids $(28,44)$ exhibit features of conditional replication in lactobacilli and these plasmids have been exploited for various integration experiments via homologous recombination. In one report of homologous recombination in an intestinal Lactobacillus strain, disruption of the lafl gene occurred via a gene disruption cassette on pSA3, which was introduced into L. johnsonii (3). In this instance, conditional replication of pSA3 was directed by manipulation of the temperature and antibiotic concentration. Disruption of the cbh gene, which codes for conjugate bile salt hydrolase, was accomplished by delivering a chloramphenicol resistance gene-containing, disruption cassette on a ColE1 replicon in L. plantarum 
(61). Similarly, Fitzsimons et al., (28) integrated an active fragment of the $\alpha$-amylase gene into the chromosome of $L$. plantarum at the $c b h$ locus by utilizing an autoreplicative plasmid. Aside from these reports, the exploitation of homologous recombination for genetic manipulation for the intestinal lactobacilli has not occurred.

\section{Gene Expression}

Cloning and characterisation of Lactobacillus genes has been accompanied by physical and phenotypic analysis of their expression signals. Many Lactobacillus genes are expressed in E. coli indicating that their expression signals are similar enough to be recognized in other bacteria (86). Moreover, phenotypic selection or complementation in $E$. coli has proven to be a successful strategy for cloning a number of genes which have been characterized to date $(124,105)$. The DNA-dependent RNA polymerase from $L$. acidophilus transcribed some, but not all $E$. coli promoters, in vitro (79). L. acidophilus promoters were also transcribed, and sequence analysis identified a -10 region similar to the $E$. coli consensus promoter sequence. Surveys of the transcriptional and translational signals of lactobacilli have revealed the following consensus sequence features (18, 86):

Promoters $-35$ $-10$

TTGACA $<17$ bp ave $>$ TATAAT

$$
\begin{array}{rrr}
\text { Ribosomal Binding Site } & \text { Start } & \text { Stop } \\
\text { AGGAGG }<6-10 \mathrm{nt} \text { ave } & \text { > AUG } & \text { UAA }
\end{array}
$$

It was noted that these should be weighted cautiously due to known exceptions (e.g. rare start codons GUG \& UUG), variation among species in \%GC content, and the relatively small number of expression regions that have been sufficiently characterized. There is some limited information about regulated promoters, RNA processing, inducers, repressors, and antiterminators in select systems described in $L$. casei (regulation of lacEGF operon transcription via transcription antitermination), L.actobacillus pentosus for xylose metabolism (negative control of $x y / A / B$ operon by a negative repressor, xylose inducer, and catabolite repression), L. plantarum (two component regulatory system for plantaricin), $L$ amylovorus (glucose repression of $\alpha$-amylase expression/secretion signals), and $L$. helveticus (SOS-like induction of helveticin J) $(25,44,29$; reviewed in 73,86$)$. Polycistronic operons have been described with contiguous and overlapping genes which can increase the efficiency of translation of downstream genes through translational coupling (reviewed in 86). Control of gene expression will be vital to food and medical applications now envisioned for the lactobacilli. In this regard, accelerated characterisation of genetic operons, expression systems, and their sensing and regulatory machinery is needed, particularly for the intestinal species.

Heterologous genes from a diverse group of microorganisms have been expressed in lactobacilli under the control of their own native heterologous promoter, a Lactobacillus promoter, or another promoter (Table 2). The current list includes genes and expression signals from gram-negative and gram-positive bacteria, sporeformers, and fungi. While expression may occur, the level can vary dramatically based on the gene, promoter, and expression host. Heterologous gene expression will allow construction of novel lactobacilli with potentially valuable properties. However, additional efforts are needed to isolate strong, weak, and regulated promoters from intestinal lactobacilli where gene expression can be controlled under the conditions in the gastrointestinal tract.

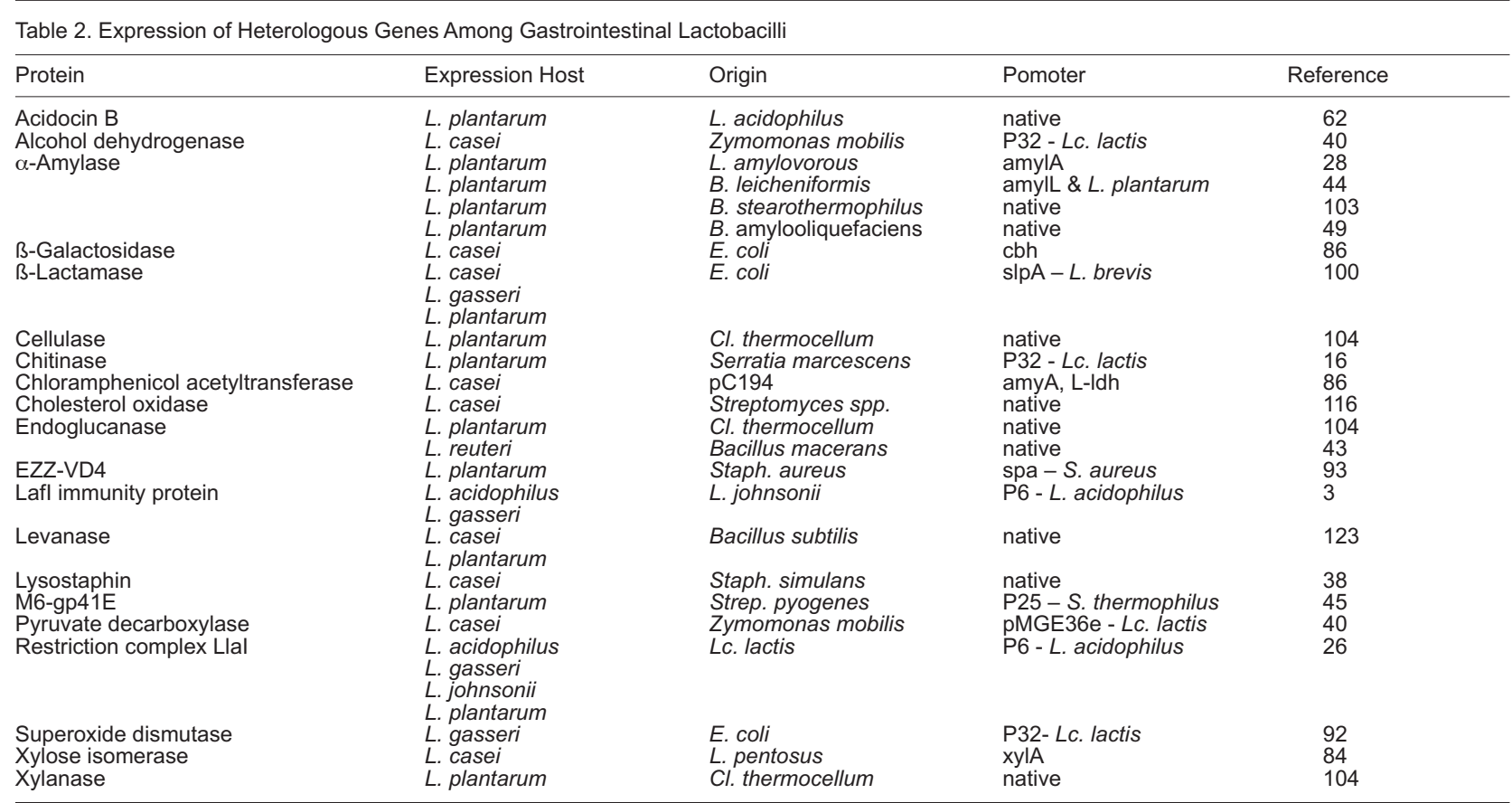


Heterologous gene expression in lactobacilli has developed a critical need to investigate and control excretion and secretion processes in order to export proteins, enzymes, and potentially antigenic epitopes. The S-layer genes of L. brevis (119) and L. acidophilus (12) have been cloned and sequenced. The regulatory and secretion signals of the $L$. brevis S-layer gene has been used in the design of highly efficient synthesis and export system for heterologous proteins and epitopes. Gene fusions to TEM- $B$-lactamase showed that the S-layer gene promoters and secretion signals functioned well in Lactococcus (Lc.) lactis, L. plantarum, and L. brevis, while in $L$. casei and $L$. gasseri, the recognition of these signals was less efficient (100). Using the Bacillus licheniformis $\alpha$ amylase gene as a reporter gene, Hols et al., (44) successfully cloned a number of $L$. plantarum expression and secretion signals capable of directing extracellular $\alpha$ amylase. The regulatory and secretion signals for $\alpha$ amylase from $L$. amylovorus are also functional in $L$. plantarum (28). An expression system in L. plantarum and L. fermentum, based upon the regulatory signals of protein A of Staphylococcus aureus was used to direct the synthesis and export of a gene fusion product, containing a region of a chlamydial major outer-membrane protein gene (93). Similarly, Hols et al., (45) designed an expression system containing the P25 promoter of $S$. thermophilus, IdhD RBS from L. pentosus, and the secretion signal of M6 protein of Streptococcus pyogenes This system was capable of the expression and secretion of a large quantity (approx. $10 \mathrm{mg} / \mathrm{L}$ culture medium) of the model antigen, M6-gp41E. Lastly, small N-terminal leader sequences with a Gly-Gly processing motif are believed to direct the excretion and activation of class IIbacteriocins $(52,117)$. LAB can use bacteriocin $A B C$ transporters to export heterologous peptide bacteriocins, using either homologous or heterologous $\mathrm{N}$-terminal extensions $(2,4,117)$. Whether or not gene fusions with these leader sequences would direct the export of heterologous, non-bacteriocin peptides or proteins has yet to be established. It is apparent, however, that signal peptide recognition and processing systems are present in lactobacilli which recognize, cleave, and secrete heterologous prepeptides.

\section{Bifidobacteria}

Bacteria in the genus Bifidobacterium were initially described by Tissier around the turn of the century. Since this time, the classification of this group has been a point of some contention and confusion. The initial classification of bifidobacteria as Bacillus plus the phenotypic and morphological attributes that they share with many lactobacilli led to the popular belief that they belonged to the genus Lactobacillus (9). Classification by molecular methodologies have provided evidence that this is indeed a distinct genus and is more closely related to the Actinomycetaceae family than to Lactobacillaceae (59, 102). As a result of their time spent in a poorly defined taxonomic position, little is known about the genetics of bifidobacteria and application of recombinant DNA technology to these organisms has been slow to occur. At present, there are 26 species of the genus Bifidobacterium $(22,101)$, but those commonly observed in the gastrointestinal tract are: $B$. adolescentis, B. animalis, $B$. angulatum, B. bifidum, B. breve, $B$. infantis and $B$. longum $(32,56,71,101)$. Sanders et al., (97) and Yaeshima et al., (125) have demonstrated the widespread presence of $B$. animalis in a variety of commercial dairy products distributed world-wide. Meile et al.,(72) recently made a description and proposal of a new species, $B$. lactis, which was isolated from a commercial yogurt. Given this strain's immediate habitat (fermented milk), very close phylogenetic proximity to $B$. animalis and the high degree of identity between the $16 \mathrm{~S}$ rRNA sequences (98.6\% over more than $1.4 \mathrm{~kb}$ ) of this strain with $B$. animalis, it is likely that $B$. lactis is represented in the $B$. animalis isolates analyzed by Sanders et al., (97) and Yaeshima et al., (125). Because of its widespread occurrence in fermented dairy foods, $B$. animalis, under any name, is certainly of significance to probiotics research from an industrial perspective.

\section{Bifidobacterial Plasmids and Vectors}

Plasmids in members of the genus Bifidobacterium were initially reported by Sgorbati et al., (106). Similar to the lactobacilli, plasmids are detected only in a few species. From bifidobacteria isolated from the human gastrointestinal tract, only $B$. longum $(83,106,107,70)$ and $B$. breve $(14,46)$ have been shown to harbor plasmids. These plasmids are all cryptic and most have not been characterised beyond restriction mapping. One cryptic plasmid, pMB1, has been sequenced and appears to encode essential replication proteins (91). The two putative replication proteins, whose genes have been designated orf1 and orf2, encoded on pMB1 show similarity to proteins encoded by plasmids pXZ10142 of Corynebacterium glutamicum and pAL500 of Mycobacterium fortuitum. It is noteworthy that, like Bifidobacterium, the genera Corynebacterium and Mycobacterium are members of the family Actinomycetaceae.

Since these first observations of plasmids, several innovations in the plasmid biology of bifidobacteria have occurred. Vectors, capable of transforming a variety of bifidobacteria, are of the general utility type with distinct replication origins and markers selectable in bifidobacteria and Escherichia coli. E. coli-Bifidobacterium shuttle vectors derived from the small cryptic plasmid described above, pMB1 $(90,91,74)$, and from other less well defined plasmids (69) have now been constructed. The first of these, pRM2 (74), contains spectinomycin ( $\mathrm{Sp}^{\mathrm{r}}$ ) and ampicillin $\left(A p^{r}\right)$ resistance determinants for selection in $B$. longum and $E$. coli, respectively. pMR2 also harbors a useful multiple cloning site, the putative origin of pMB1 and a ColE1 replication origin for $B$. longum and $E$. coli, respectively. Recently, new varieties of pMB1-based vectors have been constructed with $\mathrm{Sp}^{r}, \mathrm{Em}^{\mathrm{r}}$ and $\mathrm{Cm}^{\mathrm{r}}$ determinants for selection in bifidobacteria and the $\mathrm{Ap}^{r}$ determinant for E. coli (90). A small (2.8 kb) pMB1-based vector, pTRE3, which contains no cryptic DNA, a MCS and $\mathrm{Cm}^{r}$ was also introduced with this series of shuttle vectors. While pTRE3 does not replicate in E. coli, it demonstrates excellent segregational stability $(>95 \%$ cells harbor plasmids after 100 generations without selection) in $B$. animalis (90). In addition to the pMB1-based vectors, $E$. coli-Corynebacterium shuttle vectors have been shown to replicate in $B$. animalis (5), which is in agreement with phylogenetic positioning of these two genera. It has also been demonstrated (5) that plasmid pLP825 (85), which harbors a replicon from $L$. plantarum, and the broad host 
range Lactococcus plasmid, pGK12 (55), are incapable of transforming $B$. animalis, suggesting that the replication functions of these AT-rich plasmids are poorly recognized by bifidobacteria.

Initially, transformation efficiencies of a variety of species of bifidobacteria with these plasmids were poor and irreproducible (74), owing primarily to the fact that the procedures were designed for other bacteria. However, recent developments in transformation protocols by modification of growth medium and electric field strength (89), modification of the electroporation buffer, and preincubation of cells at $4^{\circ} \mathrm{C}$ prior to addition of DNA and electroporation (5) have dramatically increased transformation efficiency for all strains tested thus far, including those significant to probiotic research.

\section{Genetically Modified Microbes}

While there is considerable potential for genetic modification and improvement of probiotic bacteria, there are formidable barriers that will limit commercial use, public acceptance and environmental release of genetically modified organisms (GMOs), particularly those capable of colonising body cavities and mucosal surfaces. Foremost among these barriers will be public acceptance of probiotic GMOs. This is an important issue that will be faced in every instance when a probiotic GMO is considered for release. Drawing comparisons to the success of the plant biotechnology industry in the U.S.A, it could be expected that public acceptance of probiotic GMOs will improve concurrently with incremental exposure to microbial products of biotechnology that are advantageous and provide tangible benefits. Various studies have already shown that consumers in developed countries will accept products manufactured or containing GMOs, if they offer benefits to health and product quality that the consumer can clearly recognize (118). In this regard, because probiotics by definition, offer health benefits, consumers may willingly accept and use genetically modified probiotics if there are substantial and tangible benefits provided over their traditional counterparts.

Industries that manufacture lactic cultures and probiotics may also view GMOs favourably if self-imposed guidelines that adhere strictly to regulatory positions are evoked. The industry should be expected to favourably consider manufacturing GMOs if they offer a clear competitive advantage over their traditional counterparts. These advantages may reflect processing and economic gains, but the stakes can become significantly higher if health-based benefits can be associated with the probiotic $\mathrm{GMO}$, or the product used to deliver it. Again, any linkage to health and well being has the potential to favour industrial positions on probiotic GMOs if clear and tangible benefits can be realized. At this point in time, any recombinant DNA technology used to create probiotic GMOs would require strict adherence to the concepts of self cloning (using DNA originating only from the same strain/species; sequence analysis of any modifications - e.g. deletions, additions to ensure that new reading frames are not generated and that antibiotic resistance markers are not present in $\mathrm{GMO}$ ). Ultimately, any GMO would require regulatory review and safety approval. In the U.S.A., regulatory scrutiny is focused on the safety of the GMO, not the process by which it was constructed. Indeed, biotechnology occurs via precise genetic modifications where the specific genetic changes are defined and the safety of the GMO can be quickly and rationally assessed. This approach is generally applauded by scientists over "black box" mutation and selection strategies, where the genetic changes are often not known or defined. In fact, such "fry and try" strategies may be viewed in considerably less favour if in the course of genome sequencing projects, any remnants of undesirable genes (toxins, virulence factors) are uncovered in generally regarded as safe (GRAS) lactic acid bacteria. Nevertheless, probiotics are well positioned in the "natural" and "functional" food categories. Any industries aligned with manufacturing of natural and organic products would be expected to adamantly exclude GMOs and favour traditional probiotics as a more natural approach.

\section{Possible Developments}

Genetic work on probiotic lactobacilli and bifidobacteria is in its infancy but promises to be a rapidly moving field that will reap rich benefits as knowledge accumulates and new discoveries support practical applications. At this juncture, some of the more critical research areas are as follows:

- Phenotype/genotype correlation of microbial characteristics that impact on probiotic functionality

- Genome sequencing of lactobacilli and bifidobacteria

- Molecular tools and gene transfer systems to support genetic modification and self cloning

- Genetic modification to enhance existing characteristics and develop novel properties

- Molecular signatures and tags

- Investigate gene transfer and dissemination

\section{Phenotype/Genotype Correlation of Microbial Characteristics that Impact Probiotic Functionality}

Evidence supporting the in vivo roles of probiotics is needed to support the development of this industry. As such, demonstration of critical properties, genetic controls, and how they impact on in vivo functionality will be important. In this regard, the availability of the genome sequences of model probiotic species will facilitate correlation of genotypes with the capabilities and behaviour of probiotic strains. The genome project on Lactobacillus acidophilus will be completed by 2000 and is expected to fuel important efforts to understand the capabilities of lactobacilli in the gastrointestinal tract. Similarly, a genome project on Bifidobacterium should be initiated, with a model human species being a member of the $B$. longum/ $B$. infantis group.

\section{Molecular Tools and Gene Transfer Systems to Support Self Cloning}

These techniques will be needed to support genetic analysis and modification of probiotic cultures. Efforts should be intensified to construct cloning, expression, and integration vectors that are of general utility in probiotic species. In conjunction, the availability of plasmid replicons, genetic markers, promoters, and terminators that are "self", originating from the targeted probiotic species, need to be developed concurrently. It is emphasized that efficient gene delivery systems (transformation, conjugation, transduction) are vital in the conduct of any genetic analysis 
or modification of probiotic strains. The general utility and efficiency of these systems is still far below that needed to carry out genetic studies with many probiotic cultures.

\section{Opportunities to Enhance Existing Characteristics and Develop Novel Properties by Genetic Modification of Probiotic Cultures}

Potential targets for genetic modification and improvement include: immunostimulation and oral vaccine development; antimicrobials and bacteriocins; vitamin synthesis and production; adhesins and colonisation determinants; production and delivery of digestive enzymes; and metabolic engineering to alter products (e.g. polysaccharides; organic acids) or link cultures with specialty prebiotics designed to enhance the performance of a probiotic in vivo. In this regard, one attractive genetic target is to create molecular signatures or tags on the genomes of probiotic cultures. Modifications in the DNA sequence of an individual probiotic strain can be designed to allow rapid detection by specialised probes, PCR primers, or fingerprinting patterns. Molecular tags will not only allow definitive identification of novel probiotic strains, but further allow tracking their survival and dissemination through the environment or host organism. In this regard, use of new molecular methods to assess changes in the residing microbial communities $(63,78)$, upon delivery of probiotics, will be another important research area.

Lastly, it will be vitally important to begin work on gene transfer and dissemination, in vivo. Probiotic cultures are often delivered in high daily doses into the oral and intestinal cavities. Little information is currently available on gene transfer from, or to, probiotic cultures, in vivo. Investigation of the genetic routes and transfer mechanisms available for probiotics in the gastrointestinal tract, as well as the capacity for probiotics to disseminate genes, will be an important area for future research. These studies will be a vital component in the portfolio of work needed to assess the safety of genetically modified probiotics in the host and the environment.

\section{Conclusions}

Genetic manipulation of intestinal lactobacilli and bifidobacteria presents the opportunity to investigate, determine, add and improve the traits considered important for their functional roles as probiotics. The potential to present bacteria, proteins, enzymes, and antigenic epitopes in selected intestinal locations via a bacterial delivery and expression system is quickly becoming a reality. Equally important may be genetic modifications that improve their in vivo effects or allow molecular tracking of fed probiotic strains in the human gastrointestinal tract. While substantial progress has been made in this exciting field over the past decade, there remain many barriers to be overcome in defining gene transfer, expression, and control, in lactobacilli and bifidobacteria of gastrointestinal origin.

\section{Acknowledgement}

Research support for probiotics at NCSU has been provided through the North Carolina Dairy Foundation, Rhodia Inc., The Southeast Dairy Foods Research Center and Dairy Management, Inc. The authors are grateful to Douglas Christensen and John McCormick for their helpful discussion and critical review of the manuscript.

\section{Further Reading}

Tannock, G.W. Probiotics: A Critical Review. Horizon Scientific Press, Wymondham, UK

\section{References}

1. Ahrne, S., G. Molin, and Axelsson, L. 1992. Transformation of Lactobacillus reuteri with electroporation: studies on the erythromycin resistance plasmid pLUL631. Curr. Microbiol. 24: 199-205.

2. Allison, G.E., C. Ahn, M.E. Stiles, and T.R. Klaenhammer. 1995. Utilization of the leucocin A export system in Leuconostoc gelidum for production of a Lactobacillus bacteriocin. FEMS Microbiol. Lett. 131: 87-93

3. Allison, G.E. and T.R. Klaenhammer. 1996. Functional analysis of the gene encoding immunity to lactacin F, lafl, and its use as a Lactobacillus-specific, food-grade genetic marker. Appl. Environ. Microbiol. 62: 4450-4460.

4. Allison, G.E., R.W. Worobo, M.E. Stiles, and T. R. Klaenhammer. 1995 Heterologous expression of the lactacin $\mathrm{F}$ peptides by Carnobacterium pisicola LV17. Appl. Environ. Microbiol. 61: 1371-1377.

5. Argnani, A., R.J. Leer, N. van Luijk, and P.H. Pouwels. 1996. A convenient and reproducible method to genetically transform bacteria of the genus Bifidobacterium. Microbiology $142: 109-104$.

6. Aukrust, T. and I.F. Nes. 1988. Transformation of Lactobacillus plantarum with the plasmid pTV1 by electroporation. FEMS Microbiol. Lett. 52: 127-132.

7. Auvray, F., M. Coddeville, P. Ritzenthaler, and L. Dupont. 1997. Plasmid integration in a wide range of bacteria mediated by the integrase of Lactobacillus delbrueckii bacteriophage mv4. J. Bacteriol. 179: 18371845.

8. Bengmark S. 1998. Ecological control of the gastrointestinal tract. The role of probiotic flora. Gut 42: 2-7.

9. Bergey's Manual of Determinative Bacteriology, $7^{\text {th }}$ Edition. 1957. The Williams and Wilkins Co., Baltimore, MD.

10. Bhowmik, T. and J.L. Steele. 1993. Development of an electroporation procedure for gene disruption in Lactobacillus helveticus CNRZ 32. J. Gen. Microbiol. 139: 1433-1439.

11. Bhowmik, T., L. Fernandez, and J.L. Steele. 1993. Gene replacement in Lactobacillus helveticus CNRZ 32. J. Bacteriol. 175: 6341-6344.

12. Boot, H.J. C.P.A.M. Kolen, J.M van Noort, and P.H. Pouwels. 1993. S-layer protein of Lactobacillus acidophilus ATCC 4356: Purification, expression in Escherichia coli, and nucleotide sequence of the corresponding gene. J. Bacteriol. 175: 6089-6096.

13. Bouia, A., F. Bringel, L. Frey, B. Kammerer, A. Belarbi, A. Guyonvarch, and J.-C. Hubert. 1989. Structural organization of pLP1, a cryptic plasmid from Lactobacillus plantarum CCM 1904. Plasmid 22: 185192.

14. Bourget, N., J.M. Simonet, and B. Decaris. 1993. Analysis of the genome of the five Bifidobacterium breve strains: Plasmid content, pulsed-field gel electrophoresis, genome size estimation and $r r n$ loci number. FEMS Microbiol. Lett. 110: 11-20.

15. Bringel, F., L. Frey, and J.-C. Gubert. 1989. Characterization, cloning, curing and distribution in lactic acid bacteria of pLP1, a plasmid from Lactobacillus plantarum CCM 1904 and its use in shuttle vector construction. Plasmid 22: 193-202.

16. Brurberg, M.B., A.J. Haandrikman, K.J. Leenhouts, G. Venema, and I.F. Nes. 1994. Expression of a chitinase gene from Serratia marcescens in Lactococcus lactis and Lactobacillus plantarum. Appl. Microbiol. Biotechnol. 42: 108-115.

17. Chassy, B. and J. Flickinger. 1987. Transformation of Lactobacillus casei by electroporation. FEMS Microbiol. Lett. 44:173-177.

18. Chassy, B.M. and C.M. Murphy. 1993. Lactococcus and Lactobacillus, p. 65-82. In A.L. Sonenshein, J.A. Hock and R. Losick (ed.), Bacillus subtilis and other gram positive bacteria. American Society for Microbiology, Washington, DC.

19. Chassy, B.M. and E. Rokaw. 1981. Conjugal transfer of lactose plasmids in Lactobacillus casei, p. 590.In: S. Levy, R. Clowes and E. Koenig (ed.), Molecular biology, pathogenesis and ecology of bacterial plasmids. Plenum Press, New York.

20. Cocconcelli, P.S., M.J. Gasson, L. Morelli, and V. Bottazzi. 1991 Single-stranded DNA plasmid vector construction and cloning of Bacillus stearothermophilus alpha-amylase in Lactobacillus. Res. Microbiol. 142: 643-652.

21. Conway, P. 1989. Lactobacilli: Fact and fiction, p. 263-281. In R. Grubb, T. Midtvedt, T. and E. Norin (ed.), The regulatory and protective role of the normal microflora. Stockton Press, New York.

22. Crociani, F., B. Biavati, A. Alessandrini, C. Chiarini, and V. Scardovi. 1996. Bifidobacterium inopinatum sp. nov. and Bifidobacterium 
denticolens sp. nov., two new species isolated from human dental carries. Int. J. Syst. Bacteriol. 46: 564-571.

23. Crowell, D. C. 1998. Microbial analysis of human intestinal flora after feeding Lactobacillus acidophilus. M. S. Thesis, North Carolina State University.

24. Dao, M.L. and J.J. Ferretti. 1985. Streptococcus-Escherichia coli shuttle vector pSA3 and its use in cloning of streptococcal genes. Appl. Environ. Microbiol. 49: 115-119.

25. Diep, D.B., L.S. Havarstein, J. Nissen-Meyer, and I.F. Nes. 1994. The gene encoding plantaricin A, a bacteriocin from Lactobacillus plantarum $\mathrm{C} 11$, is located on the same transcription unit as an agrlike regulatory protein. Appl. Environ. Microbiol. 60: 160-166.

26. Djordjevic, G.M. and T.R. Klaenhammer. 1996. Positive selection, cloning vectors for gram-positive bacteria based on a restriction endonuclease cassette. Plasmid 35: 37-45.

27. Elmer, G.W., C.M. Surawicz, and L.V. McFarland. 1996. Biotherapeutic agents. A neglected modality for the treatment and prevention of selected intestinal and vaginal infections. J. Am. Med. Assoc. 275 870-876.

28. Fitzsimons, A., P. Hols, J. Jore, R.J. Leer, M. O'Connell, and J. Delcour. 1994. Development of an amylolytic Lactobacillus plantarum silage strain expressing the Lactobacillus amylovorus alpha-amylase gene. Appl. Environ. Microbiol. 60: 3529-3535.

29. Fremaux, C. and T.R. Klaenhammer. 1994. Helveticin J, a large heatlabile bacteriocin from Lactobacillus helveticus, p. 397-418. In L. De Vuyst and E.J. Vandamme (ed.), Bacteriocins of lactic acid bacteria: Microbiology, genetics and applications. Elsevier Applied Science Publishers, U.K.

30. Fremaux, C., C. Ahn, and T.R. Klaenhammer. 1993. Molecular analysis of the lactacin F operon. Appl. Environ. Microbiol. 59: 3906-3915.

31. Fremaux, C., G.L. De Antoni, , R.R. Raya, and T.R. Klaenhammer 1993 Genetic organization and sequence of the region encoding integrative functions from Lactobacillus gasseri temperate bacteriophage $\phi$ adh. Gene 126: 61-66.

32. Frothingham, R., A.J. Duncan, and K.H. Wilson. 1993. Ribosomal DNA sequences of bifidobacteria: Implications for sequence-based identification of human colonic flora. Microb. Ecol. Health Dis. 6: 2327.

33. Fujisawa, T., Y. Benno, T. Yaeshima, and T. Mitsuoka, 1992. Taxonomic study of the Lactobacillus acidophilus group, with recognition of Lactobacillus gallinarum sp. nov. and Lactobacillus johnsonii sp. nov. and synonymy of Lactobacillus acidophilus group A3 (Johnson et al., 1980 ) with the type strain of Lactobacillus amylovorus (Nakamura 1981). Int. J. Syst. Bacteriol. 32: 487-491.

34. Fuller, R. 1989. Probiotics in man and animals. J. Appl. Bacteriol. 66: 365-367.

35. Fuller, R. 1991. Probiotics in human medicine. Gut 32: 439-442.

36. Fuller, R. 1992. History and development of probiotics, p. 1-8. In R Fuller (ed.), Probiotics: the scientific basis. Chapman \& Hall, New York.

37. Fuller, R and G.R. Gibson, 1997. Modification of the intestinal microflora using probiotics and prebiotics. Scand. J. Gastroenterol. 222: $28-31$

38. Gaier, W., R.F. Vogel, and W.P Hammes. 1992. Cloning and expression of the lysostaphin gene in Bacillus subtilis and Lactobacillus casei. Lett. Appl. Microbiol. 14: 72-76.

39. Gilliland, S.E. 1990. Health and nutritional benefits from lactic acid bacteria. FEMS Microbiol. Rev. 7: 175-188.

40. Gold, R.S., M.M. Meagher, S. Tong, R.W. Hutkins, and T. Conway. 1996. Cloning and expression of the Zymomonas mobilis "production of ethanol" genes in Lactobacillus casei. Curr. Microbiol. 33: 256-60.

41. Havenaar, R. and J. H. J. Huis in't Veld. 1992. Probiotics: A general view, p. 209-224. In B.J.B. Wood (ed.), The lactic acid bacteria volume 1: the lactic acid bacteria in health and disease. Chapman \& Hall, New York.

42. Havenaar, R., B. ten Brink, and J. H. J. Huis in't Veld 1992. Selection of strains for probiotic use, p. 209-224. In: R. Fuller (ed.) Probiotics: The scientific basis. Chapman \& Hall, New York.

43. Heng, N.C., H.F. Jenkinson and G.W. Tannock. 1997. Cloning and expression of an endo-1,3-1,4-beta-glucanase gene from Bacillus macerans in Lactobacillus reuteri. Appl. Environ. Microbiol. 63: 3336 3340.

44. Hols, P., T. Ferain, D. Garmyn, N. Bernard, and J. Delcour. 1994. Use of homologous expression-secretion signals and vector-free stable chromosomal integration in engineering of Lactobacillus plantarum for alpha-amylase and levenase expression. Appl. Environ. Microbiol. 60: 1401-1413.

45. Hols, P., P. Slos, P. Dutot, J. Reymund, P. Chabot, B. Delplace, J. Delcour, and A. Mercenier. 1997. Efficient secretion of the model antigen M6-gp41E in Lactobacillus plantarum NCIMB 8826. Microbiology 143: 2733-2741.

46. Iwata, M. and T. Morishita. 1989. The presence of plasmids in Bifidobacterium breve. Lett. Appl. Microbiol. 9: 165-168.

47. Johnson, J.L., C.F. Phelps, C.S. Cummins, J. London, and F. Gasser, 1980. Taxonomy of the Lactobacillus acidophilus group. Int. J. Syst. Bacteriol. 30: 53-68.

48. Johnson, M. C., B. Ray, and T. Bhowmik. 1987. Selection of Lactobacillus acidophilus strains for use in "acidophilus products." Antonie van Leeuwenhoek 53: 215-231.

49. Jones, S. and P.J. Warner. 1990. Cloning and expression of alphaamylase from Bacillus amyloliquefaciens in a stable plasmid vector in Lactobacillus plantarum. Lett. Appl. Microbiol. 11: 214-219.

50. Kanatani, K., D. Yoshida, T. Tahara, K.-I. Yamada, H. Miura, M. Sakamoto, and M. Oshimura. 1992. Transformation of Lactobacillus acidophilus by electroporation with pULA105E plasmid. J. Ferment. Bioeng. 74: 358-362.

51. Klaenhammer, T.R. 1982. Microbiological considerations in selection and preparation of Lactobacillus strains for use as dietary adjuncts. J. Dairy Sci. 65: 1339-1349.

52. Klaenhammer, T.R. 1993. Genetics of bacteriocins produced by lactic acid bacteria. FEMS Microbiol. Rev. 12: 39-86.

53. Klaenhammer, T.R. 1995. Genetics of intestinal lactobacilli. Int. Dairy J. 5: 1019-1058.

54. Klein, J.R., C. Ulrich, and R. Plapp. 1993. Characterization and sequence analysis of a small cryptic plasmid from Lactobacillus curvatus LTH683 and its use for construction of new Lactobacillus cloning vecters. Plasmid 30: 14-29.

55. Kok, J., J.M.B.M. van der Vossen, and G. Venema. 1984. Construction of plasmid cloning vectors for lactic streptococci which also replicate in Bacillus subtilis and Escherichia coli. Appl. Environ. Microbiol. 48: 726-731.

56. Kullen, M.J., L.J. Brady, and D.J. O'Sullivan. 1997. Evaluation of using a short region of the recA gene for rapid and sensitive speciation of dominant bifidobacteria in the human large intestine. FEMS Microbiol. Lett. 154: 377-383.

57. Lauer, E. and O. Kandler. 1980. Lactobacillus gasserisp. nov., a new species of the subgenus Thermobacterium. Zentralbl. Bakteriol. Mikrobiol. Hyg. Abt. 1 Orig. C1: 75-78.

58. Lauer, E., C. Helming, and O. Kandler. 1980. Heterogeneity of the species Lactobacillus acidophilus (Moro) Hansen and Moquot as revealed by biochemical characteristics and DNA-DNA hybridization. Zentralbl. Bakteriol. Mikrobiol. Hyg. 1. Abt. Orig. C1: 150-168.

59. Leblond-Bourget, N., H. Philippe, I. Mangin, and B. Decaris. 1996. 16S rRNA and $16 \mathrm{~S}$ to $23 \mathrm{~S}$ internal transcribed spacer sequence analyses reveal inter- and intraspecific Bifidobacterium phylogeny. Int. J. Syst. Bacteriol. 56: 102-111.

60. Lee, Y.-K. and S. Salminen. 1995. The coming of age of probiotics. Trends Food Sci. Technol. 6: 241-245.

61. Leer, R.J., H. Christiaens, W. Verstraete, L. Peters, M. Posno, and P. H. Pouwels. 1993. Gene disruption in Lactobacillus plantarum strain 80 by site-specific recombination: Isolation of a mutant strain deficient in conjugated bile salt hydrolase activity. Mol. Gen. Genet. 239 :269272.

62. Leer, R. J., J. M. B. M. van der Vossen, M. vab Giezen, J. M. van Noort, and P. H. Pouwels, 1995. Genetic analysis of acidocin B, a novel bacteriocin produced by Lactobacillus acidophilus. Microbiology 141: 1629-1635.

63. Liu, W.T., T.L. Marsh, , H. Cheng, and L.J. Forney. 1997. Characterization of microbial diversity by determining terminal restriction fragment length polymorphisms of genes encoding 16S rRNA. Appl. Environ. Microbiol. 63: 4516-4522.

64. Luchansky, J.B., E.G. Kleeman, R.R. Raya, and T.R. Klaenhammer. 1989. Genetic transfer systems for delivery of plasmid deoxyribonucleic acid to Lactobacillus acidophilus ADH: Conjugation, electroporation, and transduction. J. Dairy Sci. 72: 1408-1417.

65. Luchansky, J.B., P.M. Muriana, and T.R. Klaenhammer. 1988. Application of electroporation for transfer of plasmid DNA to Lactobacillus, Lactococcus, Leuconostoc, Listeria, Pediococcus, Bacillus, Staphylococcus, Enterococcus, and Propionibacterium. Mol. Microbiol. 2: 637-646.

66. Luchansky, J.B., M.C. Tennant, and T.R. Klaenhammer 1991. Molecular cloning and deoxyribonucleic acid polymorphisms in Lactobacillus acidophilus and Lactobacillus gasseri. J. Dairy Sci. 74: 3293-3302.

67. Maguin, E., P. Duwat, T. Hege, D. Ehrlich, and A. Gruss. 1992. New thermosensitive plasmid for gram-positive bacteria. J. Bacteriol. 174: 5633-5638.

68. Marteau, P. and J.C. Rambaud. 1993. Potential of using lactic acid 
bacteria for therapy and immunomodulation in man. FEMS Microbiol. Rev. 12: 207-220.

69. Matsumura, H., A. Takeuchi, and Y. Kano. 1997. Construction of Escherichia coli-Bifidobacterium longum shuttle vector transforming B. longum 105-A and 108-A. Biosci. Biotechnol. Biochem. 61: 1211 1212.

70. Matteuzzi, D., P. Brigidi, M. Rossi, and D. Di. 1990. Characterization and molecular cloning of Bifidobacterium longum cryptic plasmid pMB1. Lett. Appl. Microbiol. 11: 220-223.

71. McCartney, A.L., W. Wenzhi, and G.W. Tannock. 1996. Molecular analysis of the composition of the bifidobacteria and lactobacillus microflora of humans. Appl. Environ. Microbiol. 62: 4608-4613.

72. Meile, L., W. Ludwig, U. Rueger, C. Gut, P. Kaufmann, G. Dansen, S. Wenger, and M. Teuber. 1997. Bifidobacterium lactis sp. nov., a moderately oxygen tolerant species isolated from fermented milk. System. Appl. Microbiol. 20: 57-64.

73. Mercenier, A., P.H. Pouwells, and B.M. Chassy. 1994. Genetic engineering of lactobacilli, leuconostocs, and Streptococcus thermophilus, p. 252-293. In M.J. Gasson and W.M. de Vos (ed.), Genetics and biotechnology of lactic acid bacteria. Chapman \& Hall, Blackie, Great Britain

74. Missich, R., B. Sgorbati, and D.J. LeBlanc. 1994. Transformation of Bifidobacterium longum with pRM2, a constructed Escherichia coliB. longum shuttle vector. Plasmid 32: 208-211.

75. Mitsuoka, T. 1992. The human gastrointestinal tract, p 49-114. In B.J.B. Wood (ed.), The lactic acid bacteria in health and disease, Vol I, The lactic acid bacteria in health and disease. Elsevier Science, London.

76. Muriana, P.M. and T.R. Klaenhammer. 1987. Conjugal transfer of plasmid-encoded determinants for bacteriocin production and immunity in Lactobacillus acidophilus. Appl. Environ. Microbiol. 53: 553-560.

77. Muriana, P.M. and T.R. Klaenhammer. 1991. Cloning, phenotypic expression, and DNA sequence of the gene for lactacin $F$, an antimicrobial peptide produced by Lactobacillus spp. J. Bacteriol 173: 1779-1788.

78. Muyzer, G. and K. Smalla. 1998. Application of denaturing gradient gel electrophoresis (DGGE) and temperature gradient gel electrophoresis (TGGE) in microbial ecology. Antonie Van Leeuwenhoek 73: 127-141.

79. Natori, Y., Y. Kano, and F. Imamoto. 1988. Characterization and promoter selectivity of Lactobacillus acidophilus RNA polymerase. Biochimie 70: 1765-1774.

80. Norin, K. E., A. K. Persson, H. Saxerholt, and T. Midtvedt. 1991. Establishment of Lactobacillus and Bifidobacterium species in germfree mice and their influence on some microflora-associated characteristics. Appl. Environ. Microbiol. 57: 1850-1852.

81. O'Sullivan, M. G, G. Thorton, G. C. O'Sullivan, and J. K. Collins, 1992. Probiotic bacteria: Myth or reality? Trends Food Sci. Technol. 3: $309-314$

82. O'Sullivan, D.J. and T.R. Klaenhammer. 1993. High- and low-copy number Lactococcus shuttle cloning vectors with features for clone screening. Gene 137: 227-231.

83. Park, M. S., K. H. Lee, and G. E. Ji. 1997. Isolation and characterization of two plasmids from Bifidobacterium longum. Lett. Appl. Microbiol. 25: 5-7.

84. Posno, M., P.T.H.M. Heuvelmans, M.J.F. van Giezen, B.C. Lokman, R.J. Leer, and P.H. Pouwels. 1991. Complementation of the inability of Lactobacillus strains to utilize D-xylose with D-xylose catabolismencoding genes of Lactobacillus pentosus. Appl. Environ. Microbiol. 57: 2764-2766

85. Posno, M., R.J. Leer, N. van Luijk, M.J.F. van Giezen, P.T.H.M Heuvelmans, B.C. Lokman, and P.H. Pouwels. 1991. Incompatibility of Lactobacillus vectors with replicons derived from small cryptic Lactobacillus plasmids and segregational instability of the introduced vectors. Appl. Environ. Microbiol. 57: 1822-1828.

86. Pouwels, P.H. and R.J. Leer. 1993. Genetics of lactobacilli: Plasmid and gene expression. Antonie van Leeuwenhoek 64: 85-107.

87. Raya, R.R., C. Fremaux, G.L. De Antoni, and T.R. Klaenhammer. 1992. Site-specific integration of the temperate bacteriophage $\phi$ adh into the Lactobacillus gasseri chromosome and molecular characterization of the phage $(a t t P)$ and bacterial $(a t t B)$ attachment sites. J. Bacteriol. 174: 5584-5592.

88. Rixon, J.E., G.P. Hazlewood, and H.J. Gilbert 1990. Integration of an unstable plasmid into the chromosome of Lactobacillus plantarum. FEMS Microbiol. Lett. 71: 105-110.

89. Rossi, M., P. Brigidi, and D. Matteuzzi. 1997. An efficient transformation system for Bifidobacterium spp. Lett. Appl. Microbiol. 24: 33-36.

90. Rossi, M., P. Brigidi, and D. Matteuzzi. 1998. Improved cloning vectors for Bifidobacterium spp. Lett. Appl. Microbiol. 26: 101-104.
91. Rossi, M., P. Brigidi, A. Gonzalez Vara y Rodriguez, and D. Matteuzzi. 1996. Characterization of the plasmid pMB1 from Bifidobacterium longum and its use for shuttle vector construction. Res. Microbiol. 147: 133-143.

92. Roy, D.G., T.R. Klaenhammer, and H.M. Hassan. 1993. Cloning and expression of the manganese superoxide dismutase gene of Escherichia coli in Lactococcus lactis and Lactobacillus gasseri. Mol. Gen. Genet. 239: 33-40.

93. Rush, C., L. Hafner and P. Timms, 1997. Protein A as a fusion partner for the expression of heterologous proteins in Lactobacillus. Appl. Microbiol. Biotechnol. 47: 537-542.

94. Saavedra, J. M. 1995. Microbes to fight microbes: A not so novel approach to controlling diarrheal disease. J. Pediat. Gastroenterol. Nutr. 21: 125-129.

95. Salminen, S., E. Isolauri, and E. Salminen. 1996. Clinical uses of probiotics for stabilizing the gut mucosal barrier: Successful strains and future challenges. Antonie van Leeuwenhoek 70: 347-358.

96. Sanders, M. E. 1993. Summary of conclusions from a consensus panel of experts on health attributes of lactic cultures: Significance of fluid milk products containing cultures. J. Dairy Sci. 76: 1819-1828.

97. Sanders, M. E., D. C. Walker, K. M. Walker, K. Aoyama, and T. R. Klaenhammer. 1996. Performance of commercial cultures in fluid milk applications. J. Dairy Sci. 79: 943-955.

98. Sano, K., M. Otani, Y. Okada, R. Kawamura, M. Umesaki, Y. Ohi, C. Umezawa, and K. Kanatani. 1997. Identification of the replication region of the Lactobacillus acidophilus plasmid pLA106. Gene 186: 255-262.

99. Savage, D. C. 1977. Microbial ecology of the gastrointestinal tract. Ann. Rev. Microbiol. 31: 107-33.

100. Savijoki, K., M. Kahala, and A. Palva. 1997. High level heterologous protein production in Lactococcus and Lactobacillus using a new secretion system based on the Lactobacillus brevis S-layer signals. Gene 186: 255-262.

101. Scardovi, V. 1986. Genus Bifidobacterium Orla-Jensen 1924, $472^{\mathrm{AL}}$ p. 1418-1434. In P. H. A. Sneath, N. S. Mair, M. E. Sharpe and J. G. Holt (ed.), Bergey's Manual of Systematic Bacteriology, vol. 2. The Williams \& Wilkins Co., Baltimore, MD.

102. Scardovi, V., L. D. Trovatelli, G. Zani, F. Crociani, and D. Matteuzzi. 1971. Deoxyribonucleic acid homology relationships among species of the genus Bifidobacterium. Int. J. Syst. Bacteriol. 21: 276-294.

103. Scheirlinck, T., J. Mahillon, H. Joos, P. Dhaese, and F. Michiels. 1989. Integration and expression of alpha-amylase and endoglucanase genes in the Lactobacillus plantarum chromosome. Appl. Environ. Microbiol. 55: 2130-2137.

104. Scheirlinck, T., J.D. Meutter, G. Arnaut, H. Joss, M. Claeyssens, and F. Michiels. 1990. Cloning and expression of cellulase and xylanase genes in Lactobacillus plantarum. Appl. Microbiol. Biotechnol. 33: 534541.

105. Schmidt, B.F., R.M. Adams, C. Requadt, S. Power, and S.E. Mainzer. 1989. Expression and nucleotide sequence of the Lactobacillus bulgaricus B-galactosidase gene cloned in Escherichia coli. J. Bacteriol. 171: 625-635

106. Sgorbati, B., V. Scardovi, and D.J. Leblanc, 1982. Plasmids in the genus Bifidobacterium. J. Gen. Microbiol. 128: 2121-2131.

107. Sgorbati, B., V. Scardovi, and D.J. Leblanc. 1986. Related structures in the plasmid profiles of Bifidobacterium longum. Microbiologica 94: $15-22$.

108. Shimizu-Kadota, M., M. Kiwaki, H. Hirokawa, and N. Tsuchida. 1985. ISLI: A new transposable element in Lactobacillus casei. Mol. Gen. Genet. 200: 193-198.

109. Simon, D. and A. Chopin. 1988. Construction of a vector family and its use for molecular cloning in Streptococcus lactis. Biochimie 70: 559-566.

110. Skaugen, M. and I.F. Nes. . 1994. Transposition in Lactobacillus sake and its abolition of lactocin S production by insertion of IS 1163, a new member of the IS3 family. Appl. Environ. Microbiol. 60: 2818-2825.

111. Smith, H. W. 1965. Observations on the flora of the alimentary tract of animals and factors affecting its composition. J. Path. Bacteriol. 89 : 95-122.

112. Tannock, G.W. 1995. Normal microflora. Chapman and Hall, London, U. K.

113. Tannock, G.W. 1997. Probiotic properties of lactic-acid bacteria: Plenty of scope for fundamental R \& D. Trends Biotechnol. 15: 270-274.

114. Tannock, G.W. 1987. Conjugal transfer of plasmid PAMB1 in Lactobacillus reuteri and between lactobacilli and Enterococcus faecalis. Appl. Environ. Microbiol. 53: 2693-2695.

115. Tannock, G.W., J.B. Luchansky, L. Miller, H. Connell, S. ThodeAndersen, A.A. Mercer, and T.R. Klaenhammer. 1994. Molecular characterization of a plasmid-borne (pGT633) erythromycin resistance 
determinant (ermGT) from Lactobacillus reuteri 100-63. Plasmid 31 : 60-71.

116. Thompson, K. and M. Collins. 1991. Molecular cloning in Lactobacillus helveticus by plasmid pSA3::pVA797 co-integrate formation and conjugal transfer. Appl. Microbiol. Biotechnol. 35: 334-338.

117. van Belkum, M.J., R.W. Worobo, and M.E. Stiles. 1997. Doubleglycine-type leader peptides direct secretion of bacteriocins by $A B C$ transporters: Colicin V secretion in Lactococcus lactis. Mol. Microbiol. 23: 1293-1301.

118. Verrips, C.T. and D.J.C. van den Berg. 1996. Barriers to application of genetically modified lactic acid bacteria. Antonie van Leeuwenhoek 70: 299-316

119. Vidgren, G., I. Palva, R. Pakkanen, K. Lounatmaa, and A. Palva. 1992 S-layer protein gene of Lactobacillus brevis. Cloning by polymerase chain reaction and determination of the nucleotide sequence. $J$ Bacteriol. 174: 7419-7427.

120. Vujcic, M. and L. Topisirovic. 1993. Molecular analysis of the rollingcircle replicating plasmid pA1 of Lactobacillus plantarum A112. Appl. Environ. Microbiol. 59: 274-280.

121. Walker, D.C. and T.R. Klaenhammer. 1994. Isolation of a novel IS 3 group insertion element and construction of an integration vector for Lactobacillus spp. J. Bacteriol. 176: 5330-5340.

122. Walker, D.C., K. Aoyama, and T.R. Klaenhammer. 1996 Electrotransformation of Lactobacillus acidophilus group A1. FEMS Microbiol. Lett. 138: 233-237.

123. Wanker, E., R. J. Leer, P. H. Pouwels, and H. Schwab. 1995. Expression of Bacillus subtilis levanase gene in Lactobacillus plantarum and Lactobacillus casei. Appl. Microbiol. Biotechnol. 43: 297-303.

124. Williams, S.A., R.A. Hodges, T.L. Strike, R. Snow, and R.E. Kunkee. 1984 Cloning the gene for the malolactic fermentation of wine from Lactobacillus delbrueckii in Escherichia coli and yeasts. Appl. Environ. Microbiol. 47: 288-293.

125. Yaeshima, T., S. Takahashi, N. Ishibashi, and S. Shimamura. 1996. Identification of bifidobacteria from dairy products and evaluation of a microplate hybridization method. Food Microbiol. 30: 303-313.

126. Zwahlen, M.C. and B. Mollet. 1994. ISL2, a new mobile genetic elment in Lactobacillus helveticus. Mol. Gen. Genetics. 245: 334-338.

127. Tannock, G.W. Probiotics: A Critical Review. Horizon Scientific Press, Wymondham, UK 


\section{Further Reading}

Caister Academic Press is a leading academic publisher of advanced texts in microbiology, molecular biology and medical research. Full details of all our publications at caister.com

- MALDI-TOF Mass Spectrometry in Microbiology Edited by: M Kostrzewa, S Schubert (2016) www.caister.com/malditof

- Aspergillus and Penicillium in the Post-genomic Era Edited by: RP Vries, IB Gelber, MR Andersen (2016) www.caister.com/aspergillus2

- The Bacteriocins: Current Knowledge and Future Prospects Edited by: RL Dorit, SM Roy, MA Riley (2016)

www.caister.com/bacteriocins

- Omics in Plant Disease Resistance Edited by: V Bhadauria (2016) www.caister.com/opd

- Acidophiles: Life in Extremely Acidic Environments Edited by: R Quatrini, DB Johnson (2016) www.caister.com/acidophiles

- Climate Change and Microbial Ecology: Current Research and Future Trend

Edited by: J Marxsen (2016)

www.caister.com/climate

- Biofilms in Bioremediation: Current Research and Emerging Technologies

Edited by: G Lear (2016)

www.caister.com/biorem

- Microalgae: Current Research and Applications Edited by: MN Tsaloglou (2016) www.caister.com/microalgae

- Gas Plasma Sterilization in Microbiology: Theory, Applications, Pitfalls and New Perspectives Edited by: H Shintani, A Sakudo (2016) www.caister.com/gasplasma

- Virus Evolution: Current Research and Future Directions Edited by: SC Weaver, M Denison, M Roossinck, et al. (2016) www.caister.com/virusevol

- Arboviruses: Molecular Biology, Evolution and Control Edited by: N Vasilakis, DJ Gubler (2016) www.caister.com/arbo

- Shigella: Molecular and Cellular Biology Edited by: WD Picking, WL Picking (2016) www.caister.com/shigella

-Aquatic Biofilms: Ecology, Water Quality and Wastewater Treatment

Edited by: AM Romaní, H Guasch, MD Balaguer (2016)

www.caister.com/aquaticbiofilms

- Alphaviruses: Current Biology

Edited by: S Mahalingam, L Herrero, B Herring (2016)

www.caister.com/alpha

- Thermophilic Microorganisms

Edited by: F Li (2015)

www.caister.com/thermophile
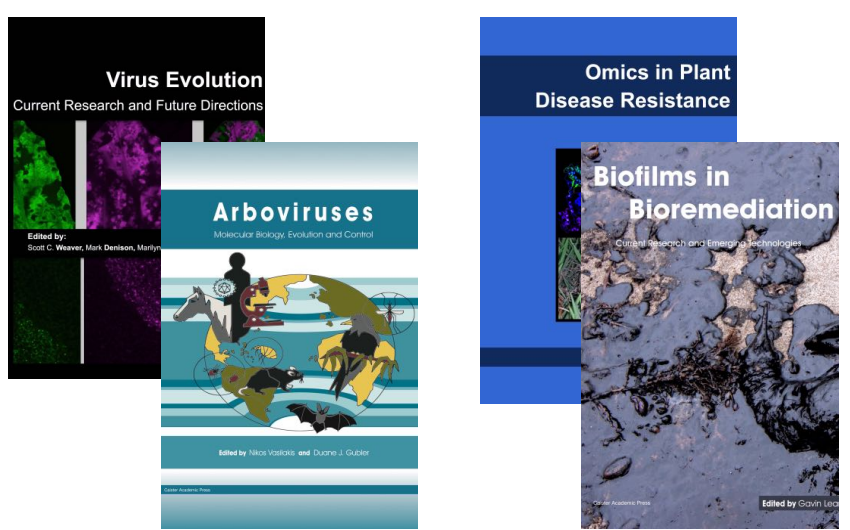
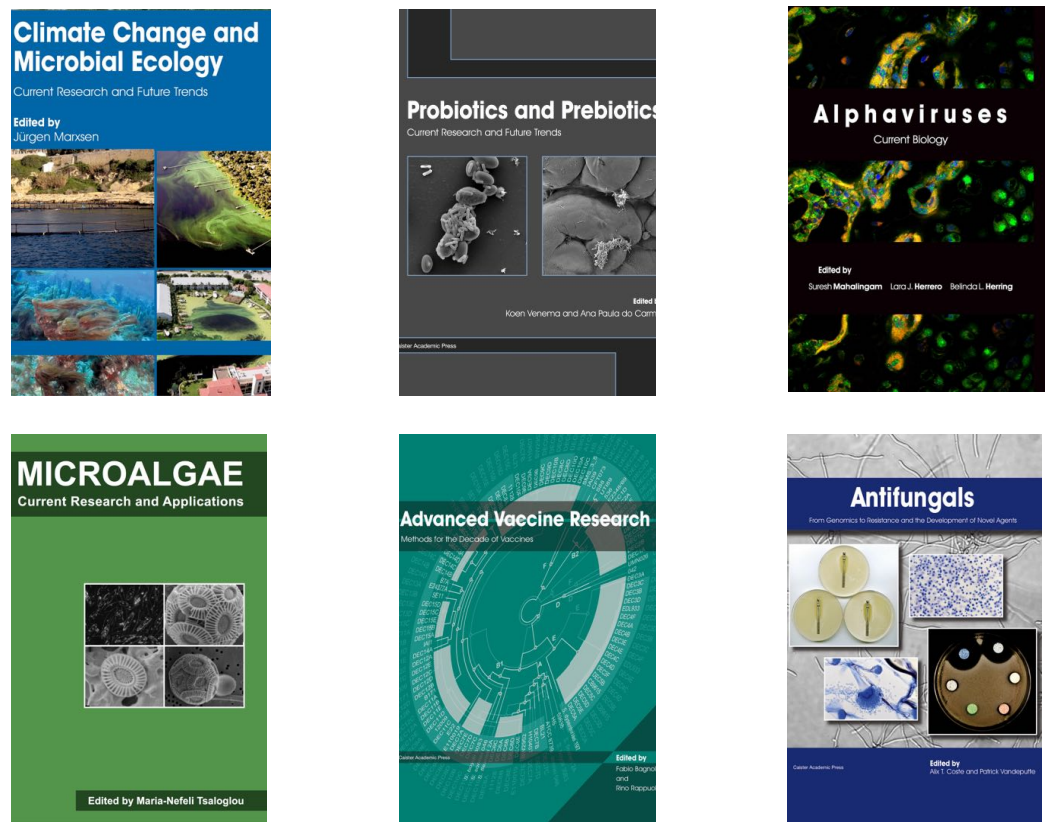

- Flow Cytometry in Microbiology: Technology and Applications Edited by: MG Wilkinson (2015) www.caister.com/flow

- Probiotics and Prebiotics: Current Research and Future Trends Edited by: K Venema, AP Carmo (2015) www.caister.com/probiotics

- Epigenetics: Current Research and Emerging Trends Edited by: BP Chadwick (2015) www.caister.com/epigenetics2015

- Corynebacterium glutamicum: From Systems Biology to Biotechnological Applications

Edited by: A Burkovski (2015)

www.caister.com/cory2

- Advanced Vaccine Research Methods for the Decade of Vaccines

Edited by: F Bagnoli, R Rappuoli (2015)

www.caister.com/vaccines

- Antifungals: From Genomics to Resistance and the Development of Novel Agents

Edited by: AT Coste, P Vandeputte (2015)

www.caister.com/antifungals

- Bacteria-Plant Interactions: Advanced Research and Future Trends Edited by: J Murillo, BA Vinatzer, RW Jackson, et al. (2015) www.caister.com/bacteria-plant

\section{- Aeromonas}

Edited by: J Graf (2015)

www.caister.com/aeromonas

- Antibiotics: Current Innovations and Future Trends

Edited by: S Sánchez, AL Demain (2015)

www.caister.com/antibiotics

- Leishmania: Current Biology and Contro Edited by: S Adak, R Datta (2015) www.caister.com/leish2

- Acanthamoeba: Biology and Pathogenesis (2nd edition) Author: NA Khan (2015)

www.caister.com/acanthamoeba2

- Microarrays: Current Technology, Innovations and Applications Edited by: Z He (2014)

www.caister.com/microarrays2

- Metagenomics of the Microbial Nitrogen Cycle: Theory, Methods and Applications

Edited by: D Marco (2014)

www.caister.com/n2 